\title{
Naproxen Derivative Interaction Properties with ct-DNA
}

\section{Naproksen Türevi ile ct-DNA'nın Etkileşim Özellikleri}

\author{
Nuriye Akbay ${ }^{1 \odot *}$, Zeynep Köksal ${ }^{1 \odot}$, Tuğba Taşkın-Tok ${ }^{\circledR}$ and Ayşe Uzgoren-Baran ${ }^{3 \odot}$ \\ ${ }^{1}$ Department of Chemistry, Istanbul Medeniyet University, Istanbul, Turkey. \\ ${ }^{2}$ Department of Chemistry, Gaziantep University, Gaziantep, Turkey. \\ ${ }^{3}$ Department of Chemistry, Hacettepe University, Ankara, Turkey.
}

ABSTRACT

nteraction mode of a naproxen derivative $(\mathrm{NH})$ with ct-DNA was explored by absorption and fluorescence spectroscopy. The experimental results revealed the static quenching as a result of groove binding between the naproxen derivative and ct-DNA. Computational studies were carried out to a deeper understanding of the interactions. Molecular docking calculations showed that the interaction between NH and ct-DNA is resulted by groove binding. In addition to spectral data, docking studies revealed that NH-A_DNA and NH-B_DNA complexes had different interaction and conformational trends to each DNA isomer.

\section{Key Words}

Quenching, groove binding, naproxen, stern-volmer.

$\mathrm{N}$ proksenin bir türevi (NH) ile ct-DNÁnın etkileşim türü absorpsiyon ve floresans spektroskopisi ile incelendi. Deneysel sonuçlar, naproksen türevi ile ct-DNA arasında oluğa bağlanma sonucunda statik sönüm gerçekleştiğini ortaya koymuştur. Hesaplamalı yöntemler de etkileşimin daha detaylı anlaşılması için kullanılmıştır. Moleküler kenetlenme hesaplamaları, NH ve ct-DNA arasındaki etkileşimin oluğa tutunma üzerinden olduğunu göstermiştir. Spektral verilere ek olarak, kenetlenme çalışmaları NH-A_DNA ve NH-B_DNA komplekslerinin her bir DNA izomerine özgü farklı etkileşim ve konformasyon eğilimlerine sahip olduğunu göstermiştir.

\section{Anahtar Kelimeler}

Sönüm, oluğa bağlanma, naproksen, stern-volmer.

Article History: Received: Jan 24, 2019; Revised: Feb 18, 2019; Accepted: Jul 18, 2019; Available Online: Sep 15, 2019

DOI: 10.15671/HJBC.517481

Correspondence to: N. Akbay, Department of Chemistry, Istanbul Medeniyet University, İstanbul, Turkey.

E-Mail: nuriye.akbay@medeniyet.edu.tr 


\section{INTRODUCTION}

Development of the tumor cell-targeted drugs is highly motivated subject because of the DNA damaging effects of the most of anticancer chemotherapeutic drugs and the limited number of DNA targeted drugs relatively to the protein targeted drugs [1]. It is important to clarify the type of interaction of possible drug molecules with DNA, to provide guidance for the application as well as to understand the reaction mechanism and to design new drugs. Three main interaction modes used to characterize the organic molecule binding to DNA are electrostatic interactions, minor and major groove binding and intercalation [2-5]. Intercalators are formed a molecular sandwich by placing planar chromophores between adjacent DNA base pairs [6]. Groove binders are generally stabilized their fixation to groove with van der Waals interactions. Hydrogen bonds, hydrophobic forces, and ionic forces are the other well-known nonbonding interactions, which stabilize the small moleculeDNA interactions [7]. Intermediate scalers form a molecular sandwich by placing planar chromophores between adjacent DNA base pairs.

Naproxen is a commonly used nonsteroidal antiinflammatory drug (NSAID) of the propionic acid class. The new generation of naproxen derivatives attracts attention because of naproxen's high side effects in long term use. When the studies in the literature were examined, it was observed that the side effects were reduced in the naproxen structures where the acid group was protected [8-9].

Although hydrazide compounds are generally used as starting materials in the synthesis of acyl hydrazone compounds, medicinal and drug discovery chemists investigations are continuous to reveal the biological potentials of these compounds [10]. At this point study of the interaction of these compounds with nucleic acids has a place in the steps of the transition of biologically active compounds into drugs.

In this study, microwave irradiation method, inspired by recent studies and the latest trends in the use of environmentally friendly techniques, was used as a green method in the synthesis of naproxen hydrazide. By using this technique, the reaction was carried out only in $3 \mathrm{~mL}$ absolute ethanol for 20 minutes. ct-DNA interactions of the chosen naproxen derivative were systematically studied by molecular docking technique,
UV-Vis absorption spectroscopy, and fluorescence spectroscopy. Quenching and binding properties of the interactions were characterized and an interaction mechanism was suggested for the studied system. We believe that these results reveal contribution to designing new and effective naproxen derivatives and understanding the effective usage of this group drugs.

\section{MATERIALS and METHODS}

Preparation and characterization of 2-(6-methoxynaphthalen-2-yl)-propionic acid hydrazide (NH)

Conventional synthesis of compound $\mathrm{NH}$ is already known in the literature [11]. In this study, naproxen hydrazide was synthesized in the minimum amount of ethanol under microwave irradiation (Figure 1). The starting compound N-[2-(6-methoxy-2-naphthyl) propanoyloxy]succinimide (1) was prepared by employing the previously reported procedures [12]. In brief, naproxen reacted with $\mathrm{N}$-hydroxysuccinimide in the presence of catalytic amount of DCC to give the desired compound. The melting point of the compound is compatible with the literature. Therefore, the compound was used without any further analysis in the next step of the reaction.

In the synthesis of compound $\mathrm{NH}$, a mixture of 2-(6-methoxy-naphthalene-2-yl)-propionic acid ester (1) $(1 \mathrm{~g}, 3.3 \mathrm{mmol})$ and hydrazine hydrate $(3.0 \mathrm{~mL})$ was added into $3 \mathrm{ml}$ ethyl alcohol and placed teflon microwave vessels. This mixture was heated in a microwave oven for a $20 \mathrm{~min}$ at $100 \mathrm{~W}$. The residue obtained at the end of the reaction was poured into water. The solid product was separated by filtration and dried to obtain the desired product $\mathrm{NH}$. The purified compound was obtained by recrystallization in absolute ethanol (Yield: $81 \%)$. Melting point, elementary analysis, $1 \mathrm{H}$ - and APT-NMR and IR measurements were used in the characterization of the compound. All spectral data are consistent with the literature.

\section{Reagents}

The chemicals except naproxen used in studies were obtained from Sigma-Aldrich Chemical Co. 2.0x10$3 \mathrm{M}$ stock solution of $\mathrm{NH}$ was prepared in DMSO and used all throughout the studies. Naproxen was kindly supplied by Atabay Pharmaceuticals. A sodium salt of calf thymus deoxyribonucleic acid was used to prepare the stock ct-DNA solution in Tris- $\mathrm{HCl}$ buffer solution at 
<smiles>COc1ccc2cc(C(C)C(=O)ON3C(=O)CCC3=O)ccc2c1</smiles>

Figure 1. Synthetic pathways of 2-(6-methoxy-naphthalen-2-yl)-propionic acid hydrazide (NH).

$\mathrm{pH}$ 8.0. Absorption values of the solution at $260 \mathrm{~nm}$ (molar coefficient: $6600 \mathrm{M}-1 \mathrm{~cm}-1$ ) were used to get the concentration of the solution. Using the absorption values ratio of the DNA solution at 260 and $280 \mathrm{~nm}$ is one of the simplest methods to check the purity of the used DNA and this method used in this study. Prepared ct-DNA solution gave a ratio of A260/A280 > 1.8. and used without further purification. Appropriate dilutions were made before using the stock solutions in daily use and all stock solutions were stored in the refrigerator at $4^{\circ} \mathrm{C}$ till use.

\section{Apparatus}

Steady-state fluorescence measurements and the absorption measurements were obtained by FS5spectrofluorimeter (Edinburgh Instruments). In the measurements were carried out in $1.0 \mathrm{~cm}$ quartz cell by using $150 \mathrm{~W}$ xenon lamp source. Bandpass slits of excitation and emission were adjusted as 3 and $5 \mathrm{~nm}$ for all studies, respectively. a Milestone-RotaPREP microwave oven was used for microwave irradiation source. $\mathrm{pH}$ measurements were carried out with Ohaus Starter $3100 \mathrm{pH}$ meter.

\section{Fluorescence titrations and UV-Vis Absorption}

Spectrophotometric titrations of the $\mathrm{NH}$ by ct-DNA was carried out by adding an increasing amount of ct-DNA to the working system (fixed concentration of $\mathrm{NH}=5.0 \times 10-6 \mathrm{~mol} / \mathrm{L}$ in $2.0 \mathrm{~mL}$ Tris- $\mathrm{HCl}$ buffer; $\mathrm{pH} 8.0$ ). Fluorescence titrations also were performed in the same way with the spectrophotometric titrations. The temperature dependence of the fluorimetric titrations was investigated by performing the titrations at two different temperature $\left(25\right.$ and $\left.45^{\circ} \mathrm{C}\right)$. The fluorescence emission spectra of $\mathrm{NH}$ were collected between 320 $440 \mathrm{~nm}$ upon excitation at $236 \mathrm{~nm}$.

\section{Competitive displacement assay}

Interaction mode of the complexes with ct-DNA was also explored using ethidium bromide (EB) competitive displacement assay. The measurements were carried on the fixed ethidium bromide and DNA concentrations. Various amount of NH were added onto the EB-ct-DNA complex. All experiments were performed at room temperature.

In a competitive displacement assay, EB-ct-DNA complex was formed by mixing the $1.97 \mu \mathrm{g} / \mathrm{mL}$ EB and $19.8 \mu \mathrm{g} / \mathrm{mL}$ ct-DNA and the concentrations were fixed all along the experiments. Obtained EB-ct-DNA complex was titrated by adding various amounts of $\mathrm{NH}$ on it. Fluorescence emission spectra were recorded between $310-420 \mathrm{~nm}$ upon excitation of the system at $236 \mathrm{~nm}$.

\section{Docking calculation}

In this part of the study, DNAs and compound were prepared as the previous study [13] for molecular docking calculations. Blind docking methodology was used to analyzing the interaction mechanism of the ct-DNA with NH by using AutoDock 4.2 [14]. It predicts the possible $\mathrm{NH}$ binding mode on the whole DNA target and evaluating its binding affinity using scoring systems. A rigid target and a flexible $\mathrm{NH}$ compound were identified (for 100 independent runs per compound) with Lamarckian genetic algorithm for this method. The grid was set up 126, 126, and 126 points in $x, y$ and $z$ directions with a grid spacing of $0.375 \AA$. The energetic map was calculated by using a distance-dependent function of the dielectric constant. Docking results were assessed with the help of the calculated binding energy and inhibition constant (Ki) values of $\mathrm{NH}$ and DNAs.

\section{RESULTS and DISCUSSION}

Interaction of the small molecules with nucleic acids or proteins is a continuous working area because of the need of new drugs. Fluorescence quenching method provides a useful technique for understanding the interaction of the small organic molecules with nucleic acids because of ease in its application. Fluorescence quenching can 
Table 1. Interaction parameters of $\mathrm{NH}$ and ct-DNA complex at various temperatures.

\begin{tabular}{cccc}
\hline & & & $\mathrm{NH}$ \\
\hline & $\left.\mathrm{K}^{\circ} \mathrm{C}\right)$ & $\mathrm{K}$ & $\mathrm{n}$ \\
\hline 298 & 5.65 & $8.93 \times 103$ & 1.05 \\
\hline 318 & 4.60 & $2.12 \times 104$ & 1.18 \\
\hline
\end{tabular}

be defined as the decrease in fluorescence intensity upon interaction of the fluorophore with any quencher. In this study, we aimed to search the possibility of obtaining the more effective naproxen derivative for DNA target treatments and then deducing the binding characteristics of the chosen derivative by using quenching effect of ct-DNA on fluorescence spectra of naproxen derivative. Fluorescence quenching spectra of the NH upon addition of ct-DNA was shown in Figure 2. The observed results showed that the increase of ct-DNA amount caused the gradual decrease in the

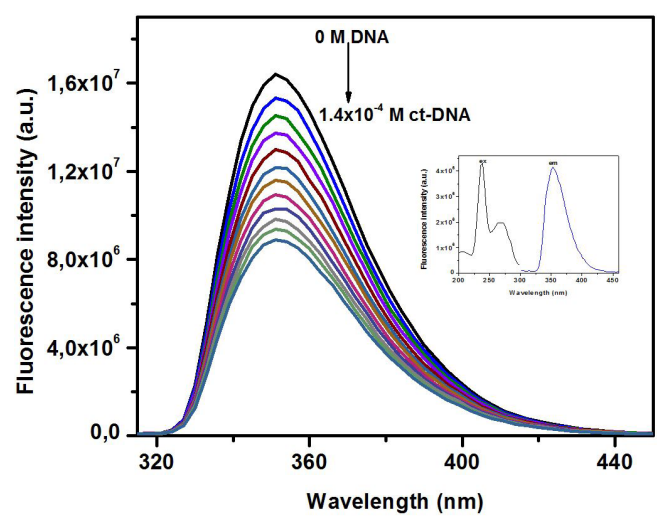

Figure 2. Fluorescence emission of $\mathrm{NH}$ in the presence of ctDNA $\left(\lambda_{\text {ex }}=236 \mathrm{~nm}, C_{\text {ct-DNA }}: 0,1.00,2.65,3.97,5.28,6.59,7.89\right.$, $9.00,10.47,11.75,13.02,14.29\left(\times 10^{-5}\right) \mathrm{M}$, from highest curve to lowest).

(A)

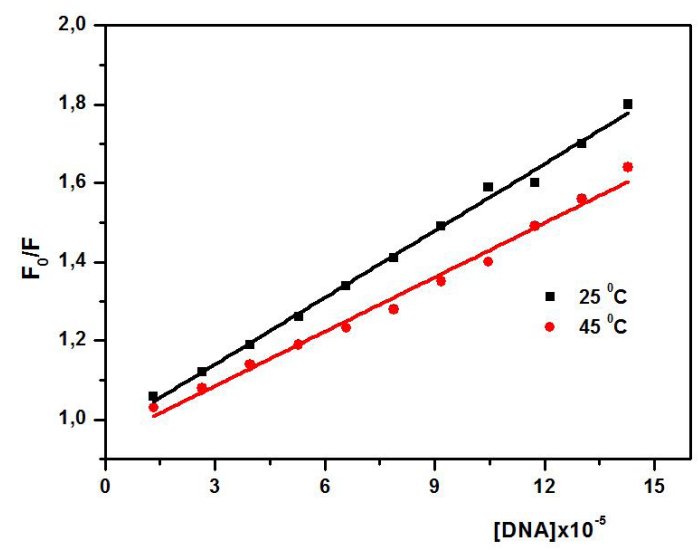

fluorescence intensity of $\mathrm{NH}$. Beside that, the maximum emission wavelength and the shape of the band stayed unchanged. Evaluated experimental data deduced by using Stern-Volmer equation (1) to understand the nature of the fluorescence quenching of the $\mathrm{NH}$ by ctDNA [15];

$\mathrm{FO} / \mathrm{F}=1+\mathrm{Ksv}[\mathrm{Q}]$

$\mathrm{FO}$ : Initial fluorescence intensity of $\mathrm{NH}$

F: Fluorescence intensity of $\mathrm{NHs}$ after the addition of the ct-DNA

KSV: The Stern-Volmer quenching constant

[Q]: The concentration of quencher (ct-DNA)

Stern-Volmer graphs were interpreted from the performed fluorimetric titrations data at two temperatures and shown in Figure 3(A). Slopes of the graphs were used to get Ksv values of the NH-ct-DNA system and the decrease in values by the increase in temperature was observed. This result points the static quenching as probable quenching mechanisms of $\mathrm{NH}$ by ct-DNA. Table 1 shows the obtained numerical results from graphs.

Double logarithm regression curves can be used to evaluate the binding constants $(\mathrm{Kb})$ and the number of binding sites ( $n$ ) of the complex systems. Following

(B)

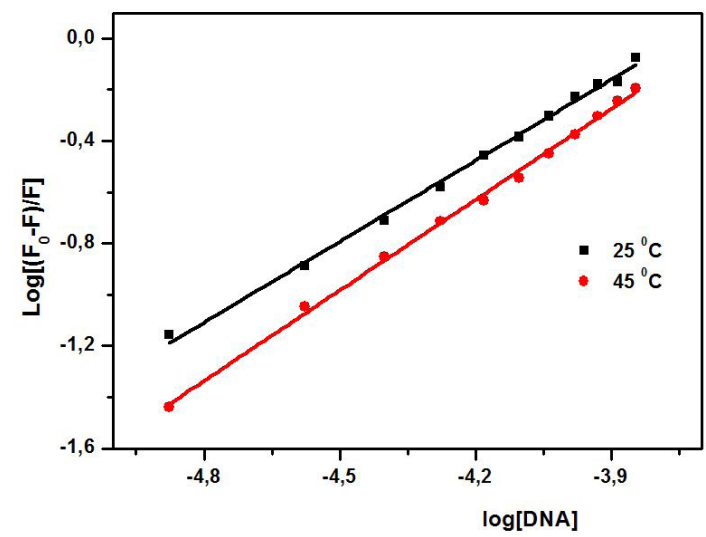

Figure 3. (A) The Stern-Volmer plot of NH-ct-DNA system at different temperatures; (B) double-log plot of NH-ct-DNA system at different temperatures. 
equation (2) was applied to get the $\mathrm{Kb}$ and $\mathrm{n}$ values of the complex of $\mathrm{NH}$ and ct-DNA by using the obtained data from fluorescence quenching process [16];

$$
\log (F O-F / F)=\log K b+n \log [Q]
$$

The obtained $\mathrm{Kb}$ and $\mathrm{n}$ values of $\mathrm{NH}$ with ct-DNA) from the intercept and slope of double logarithm regression curve (Figure 3(B)) were listed in Table 1. At the higher temperatures, greater binding constants observed and the increase in temperature can be interpreted as the increment in complex stability. Binding type of fluorescent probe with ct-DNA determines the sensitivity to environmental changes. Intercalators are highly inaccessible as a result of the protection provided by adjacent base pairs. Oppositely, groove binders are mostly objective for environmental changes. Heavy atom quenching on fluorescence systems is a well-known effect of heavy atoms. In this study iodide accessibility of the $\mathrm{NH}$ as a fluorescent probe was investigated by a series of studies. Effect of iodide ion and correlation of its effect with iodide concentration are investigated by adding $\mathrm{KI}$ solution into $\mathrm{NH}$-ct-DNA system. The decrease in fluorescence intensity of the system upon an increasing amount of iodide in the medium was observed (Figure 3). In the consideration of

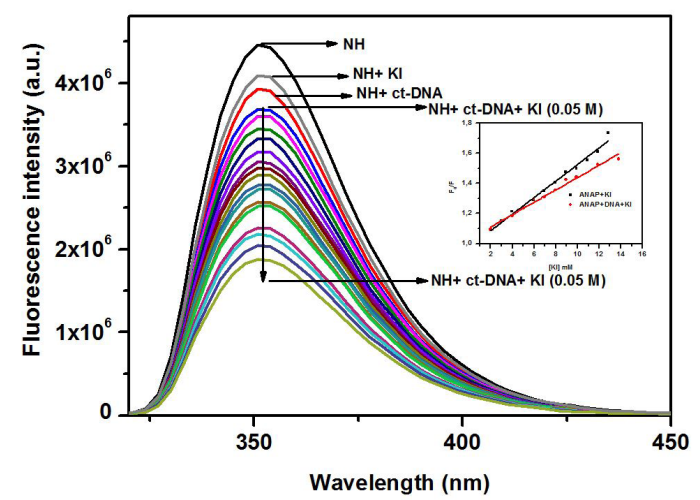

Figure 4. lodide ion quenching effect on the fluorescence emission spectra of $\mathrm{NH}$-ct-DNA complex. Inset refers to the Stern-Volmer plots free $\mathrm{NH}$ and $\mathrm{NH}$-ct-DNA complex system in the presence of $\mathrm{KI}$.

the obtained results, groove binding can be suggested in the interaction of $\mathrm{NH}$ with ct-DNA.

\section{Absorption properties in the presence of ct-DNA}

Absorption spectra characteristics of fluorescent probes in the presence and absence of DNA can distinguish the interaction type between probe and DNA. Effects of the various amounts of ct-DNA on the absorption properties of the $\mathrm{NH}$ were investigated and the spectra were shown in Figure 5. The absorption spectra of
$\mathrm{NH}$ have two distinct absorption bands around 236 and $275 \mathrm{~nm}$ and a small absorption band around $340 \mathrm{~nm}$. The origin of the distinct bands observed in the absorption spectra can be the core structure of compounds. Hypochromic and bathochromic effects of the intercalation are well-known characteristics while the hyperchromic effect and a spectral shift come with groove binding [17]. The increment in the absorption of the $\mathrm{NH}$-ct-DNA system upon increment the concentration of the added ct-DNA. Despite the hyperchromicity and mild spectral shift of the bands, the shape of the bands stayed almost unaltered. These

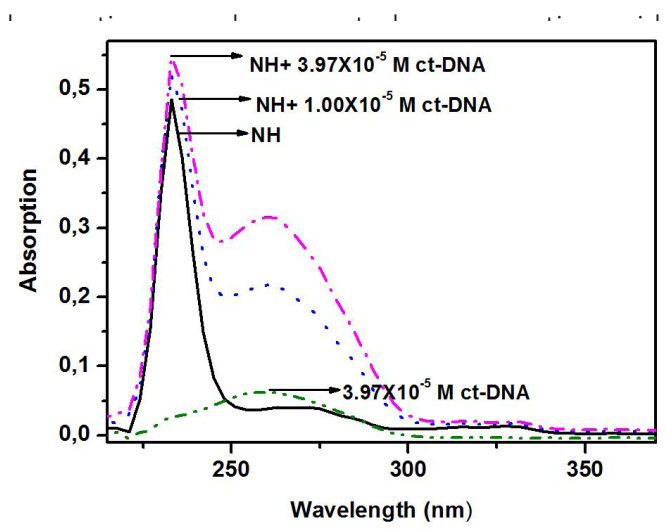

Figure 5. ct-DNA effect on the UV-vis absorption spectra of $\mathrm{NH}(\mathrm{pH}=8.0)$.

for the groove binding between $\mathrm{NH}$ and ct-DNA.

\section{Competitive Displacement Assay}

EB is a well-known interactive DNA binding probe [18]. To further examination of the binding mode of naproxen derivative with ct-DNA, a competitive displacement assay were carried out with EB. The weak fluorescence intensity of the EB increases upon intercalation between base pairs of ct-DNA. However, in the presence of another intercalator, the fluorescence of EB-ct-DNA complex can be quenched as a result of displacement of intercalator with EB [19]. Effect of the $\mathrm{NH}$ on the

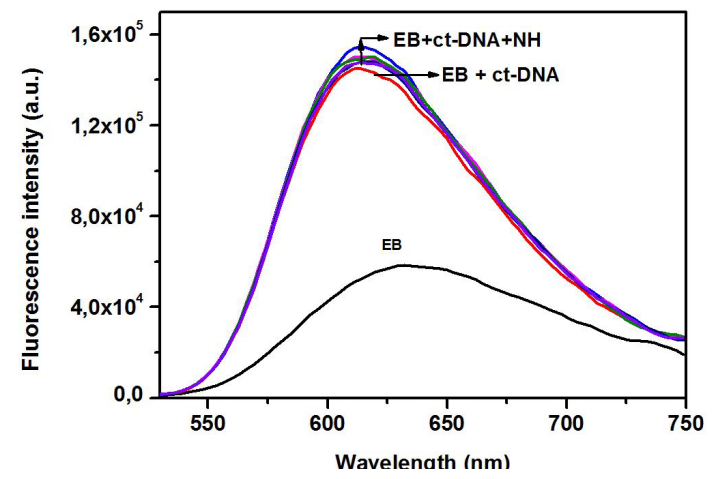

Figure 6. Effect of the NH on the fluorescence emission of the EB-ct-DNA complex. 
fluorescence emission of the EB-ct-DNA system is shown in Figure 6.

$\mathrm{NH}$ additions have resulted in an insignificant increase $\mathrm{NH}$ additions have resulted in an insignificant increase of the fluorescence intensity of the system. This result suggested that the interaction between $\mathrm{NH}$ and ct-DNA can take place via groove binding and the probe is not capable to replace with EB, which is located between adjacent base pairs of the ct-DNA duplex. The results are consistent with UV-vis absorption studies.

\section{Thermodynamic results of the binding between NH and ct-DNA}

Main forces in the small molecule-target interactions can be classified into 5 main groups. Those are electrostatic interaction, hydrophobic forces, hydrogen bonds, van der Waals forces, and covalent bonds. The type of the driven force between the probe and ct-DNA can be proposed from the values of the thermodynamic parameters such as $\Delta \mathrm{H}, \Delta \mathrm{G}$ and $\Delta \mathrm{S}$. The following two equations numbered as equation 3 and 4 are used to obtain the thermodynamic parameters of the investigated system at two temperatures.

$$
\begin{aligned}
& \ln K 2 / K 1=-\Delta H / R[1 / T 2-1 / T 1] \\
& \Delta G=\Delta H-T \Delta S=-R T \ln K
\end{aligned}
$$

Binding constant values obtained at 25 and $45^{\circ} \mathrm{C}$ for $\mathrm{NH}$ ct-DNA complex system were used as $\mathrm{K} 1$ and $\mathrm{K} 2$ values in the calculations. Gibbs free energy value $(\Delta G)$ was calculated for $25^{\circ} \mathrm{C}$ and used further calculations. The obtained thermodynamic values have interpreted the literature [20-21].

Table 2 represents the obtained thermodynamic results of the investigated system. Hydrophobic interactions were suggested as main interactions since positive

Table 2. Evaluated thermodynamic parameters of the $\mathrm{NH}$-ct-DNA system.

\begin{tabular}{lllll}
\hline Derivative & $\begin{array}{l}\Delta \mathrm{H}(\mathrm{kJ} / \\
\mathrm{mol})\end{array}$ & $\begin{array}{l}\mathrm{T} \Delta \mathrm{S}(\mathrm{K} . \mathrm{kJ} / \\
\mathrm{mol})\end{array}$ & $\begin{array}{l}\Delta \mathrm{G}(\mathrm{kJ} / \\
\mathrm{mol})\end{array}$ & $\begin{array}{l}\text { Interac- } \\
\text { tion mode }\end{array}$ \\
\hline $\mathrm{NH}$ & 33.54 & 56.08 & -22.54 & $\begin{array}{l}\text { Hydropho- } \\
\text { bic forces }\end{array}$
\end{tabular}

A)

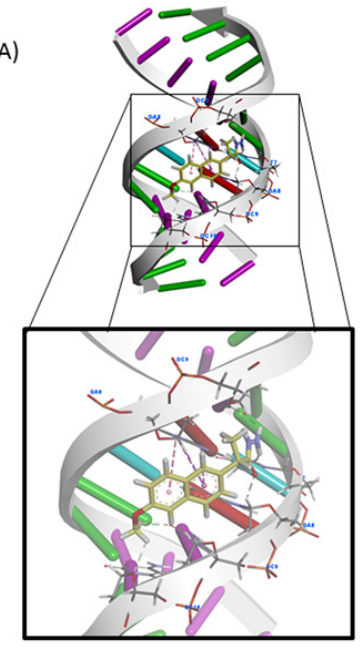

Figure 7. Docking poses and interactions of compound $\mathrm{NH}$ in A_DNA (A) and B_DNA (B).

values of $\Delta \mathrm{H}$ and $\Delta \mathrm{S}$ in the binding interactions of $\mathrm{NH}$ to ct-DNA. Probe and ct-DNA interactions were accepted spontaneous because of the negative value of $\Delta G$ [22].

\section{Docking Results}

Molecular docking studies were performed for the elucidation of the molecular interactions between $\mathrm{NH}$ compound and DNAs. The docked NH-A_DNA and $\mathrm{NH}-\mathrm{B}-\mathrm{DNA}$ complexes and their three-dimensional interactions are shown in Figure 7. The NH-A_DNA complex has five hydrogen bonds with active nucleotides A: DT7, B: DC9, A: DA8, A: DC10 and A: DC9, and four hydrophobic interactions with active nucleotide B: DA8, (Table 3). In addition, interaction with $\mathrm{NH}$ compound with B-DNA reveals that hydrogen bonds were dominant, not available other interaction at Figure 7 (B). Besides these interactions of both complexes, modes of $\mathrm{NH}$ compounds were different in each DNA isomer. Ki values and binding energy for each complex were obtained the end of the docking calculations and represented in Table 4. Based on the experiment part, NH-A_DNA complex data are more suitable than NH-B_DNA complex data. In conclusion, it is shown that

Table 3. EThe interaction type of the complex and thermodynamic analysis results.

\begin{tabular}{ccc}
\hline Complex & $\Delta \mathrm{G}(\mathrm{kcal} / \mathrm{mol})$ & $\mathrm{K}_{\mathrm{i}}(\mathrm{uM})$ \\
\hline NH-A-DNA & -5.87 & 50.10 \\
\hline NH-B-DNA & -7.90 & 1.61 \\
\hline
\end{tabular}




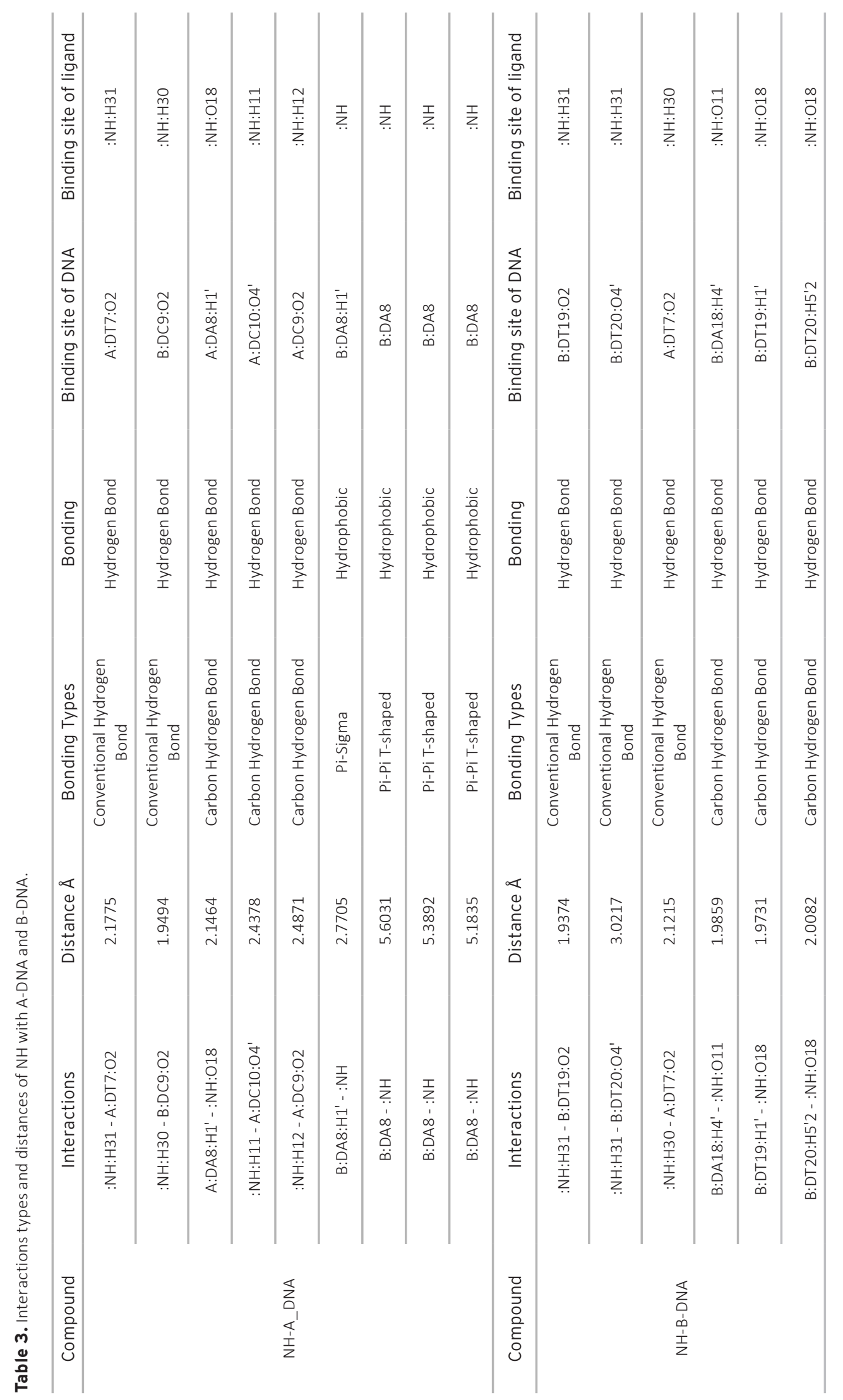


hydrophobic interactions have a dominant effect on $\mathrm{NH}$-DNA interaction. Moreover, additional information about the optimized $\mathrm{NH}$ compound was given at Figure S1 and TS1 in supporting information part.

\section{CONCLUSION}

The results of the interaction of ct-DNA with a naproxen derivative were revealed;

1.The main quenching mechanism is static quenching in the NH-ct-DNA complex system.

2.The binding occurs spontaneously.

3.Positive $\Delta \mathrm{H}$ and positive $\Delta \mathrm{S}$ values point the hydrophobic interactions as a driven force in the $\mathrm{NH}$-ct-DNA complex. 4.UV-vis absorption, a competitive binding assay with EB-ct-DNA complex and iodide ion quenching effect results indicate the groove binding between ct-DNA and derivative.

5.Theoretical results with docking interactions and $\mathrm{NH}$ modes with DNA back up the experimental results.

6.Docking results revealed that $\mathrm{NH}$ compound has a valuable effect with the help of the different research techniques.

\section{Acknowledgement}

This work was supported by the Scientific and Technical Research Council of Turkey (TUBITAK) - Grant No 114Z391. The numerical calculations reported in this study were performed at TUBITAK ULAKBIM, High Performance and Grid Computing Center (TRUBA resources).

\section{References}

1. M.A. Husain, Z. Yaseen, S.U. Rehman, T. Sarwar, and M. Tabish, Naproxen Intercalates with DNA and Causes Photocleavage Through ROS Generation, The FEBS Journal, 24 (2013) 65 69-6580.

2. K. Gurova, New hopes from old drugs: revisiting DNA binding small molecules as anticancer agents, Future Oncol. 5 (2009) 1685-1704.

3. D.R. Boer, A. Canals, and M. Coll, DNA-binding drugs caught in action: the latest 3D pictures of drug-DNA complexes, Dalton Trans., 3 (2009) 399-414.

4. U. Pindur, M. Jansen, and T. Lemster, Advances in DNA ligands with groove binding, intercalating and/or alkylating activity: chemistry, DNA-binding and biology, Curr. Med. Chem., 12 ( 2005) 2805-2847.

5. L. Strekowskı and B. Wilson, Noncovalent interactions with DNA: an overview, Mutat Res-Fund Mol M., 623 (2007) 3-13.

6. J. Li, B. Li, Y. Wu, S. Shuang, C. Dong, and M. Choi, Luminescence and binding properties of two isoquinoline alkaloids chelerythrine and sanguinarine with ctDNA, Spectrochim Acta A Mol. Biomol. Spectrosc., 95 (2012) 80-85.
7. Y. Temerk, M. Ibrahim, H. Ibrahim, and M. Kotb, Interactions of an anticancer drug Formestane with single and doublestranded DNA at physiological conditions, J. Photochem. Photobiol. B., 149 (2012) 27-36.

8. L. J. Marnett and A. S. Kalgutkar, Design of selective inhibitors of cyclooxygenase-2 as nonulcerogenic anti-inflammatory agents, Curr. Opin. Chem. Biol., 2 (1998) 482-490.

9. A.S. Kalgutkar, A.B. Marnett, B.C. Crews, R.P. Remmel, and L. J. Marnett, Ester and amide derivatives of the nonsteroidal antiinflammatory drug, indomethacin, as selective cyclooxygenase-2 inhibitors, J. Med. Chem., 43 (2000) 2860-2870.

10. Y.C. Kim, Y. Karton, X.D. Ji, N. Melman, J. Linden, and K. A. Jacobson, Acyl-hydrazide derivatives of a xanthine carboxylic congener (XCC) as selective antagonists at human A2B adenosine receptors, Drug Dev. Res., 47 (1999) 178-188.

11. M. Nakka, M.S. Begum, B.F.M. Varaprasad, L.V. Reddy, A. Bhattacharya, M. Helliwell, Naproxen and ibuprofen based acyl hydrazone derivatives: Synthesis, structure analysis and cytotoxicity studies. J. Chem. Pharm. Res., 2 (2010) 393-409.

12. D. Sarigol, A. Uzgoren-Baran, B.C. Tel, E.I. Somuncuoglu, I. Kazkayasi, K. Ozadali-Sari, et al., Novel thiazolo [3, 2-b]-1, 2, 4-triazoles derived from naproxen with analgesic/antiinflammatory properties: Synthesis, biological evaluation and molecular modeling studies, Bioorg. Med. Chem., 23 (2015) 2518-2528.

13. S. Ozkan, T. Taskin Tok, A. Uzgoren Baran, and N. Akbay, Multispectroscopic and Computational Investigation of ct-DNA Binding Properties with Hydroxybenzylidene Containing Tetrahydrocarbazole Derivative, J. Fluoresc., (2018) 1-10.

14. G.M. Morris, R. Huey, W. Lindstrom, M.F. Sanner, R.K. Belew, D.S. Goodsell, et al. AutoDock4 and AutoDockTools4: Automated Docking with Selective Receptor Flexibility, J. Comput. Chem., 30 (2009) 2785-2791.

15. J.R. Lakowicz, Plasmonics in biology and plasmon-controlled fluorescence, Plasmonics, 1 (2006) 5-33.

16. Y.Q. Wang, H.M. Zhang, G.C. Zhang, Studies of the interaction between palmatine hydrochloride and human serum albumin by fluorescence quenching method, J. Pharmaceut. Biomed., 41 (2006) 1041-1046.

17. M. Wu, W. Wu, X. Lian, X. Lin, and Z. Xie, Synthesis of a novel fluorescent probe and investigation on its interaction with nucleic acid and analytical application, Spectrochim. Acta A Mol. Biomol. Spectrosc., 71 (2008) 1333-1340.

18. H.G. Li, Z.Y. Yang, B.D. Wang, and J.C. Wu, Synthesis, crystal structure, antioxidation and DNA-binding properties of the Ln complexes with 1-phenyl-3-methyl-5-hydroxypyrazole4-carbaldhyde-(benzoyl) hydrazone, J. Organomet. Chem., 695 (2010) 415-422.

19. I. Ahmad, A. Ahmad, M. Ahmad, Binding properties of pendimethalin herbicide to DNA: multispectroscopic and molecular docking approaches, Phys. Chem. Chem. Phys., 18 (2016) 6476-85

20. Y.T. Sun, S.Y. Bi, D.Q. Song, C.Y. Qiao, D. Mu, H.Q. Zhang, Study on the interaction mechanism between DNA and the main active components in Scutellaria baicalensis Georgi, Sensor. Actuat. B-Chem., 129 (2008) 799-810.

21. P.D. Ross, S. Subramanian, Thermodynamics of Protein Association Reactions - Forces Contributing to Stability, Biochemistry-Us, 20 (1981) 3096-102.

22. S.Y. Bi, L.L. Yan, Y.T. Sun, H.Q. Zhang, Investigation of ketoprofen binding to human serum albumin by spectral methods, Spectrochim. Acta A., 78 (2011) 410-414. 